\title{
Analisis Pelaksanaan Pelayanan Pendidikan Melalui Online Di Masa Pandemi Covid-19 Pada SDIT Bina Cendikia, Depok
}

\author{
Munarsih \\ Program Studi Manajemen, Fakultas Ekonomi, Universitas Pamulang, Tangerang \\ dosen02448@unpam.ac.id
}

\begin{abstract}
Abstrak
Tujuan penelitian untuk mengetahui pelaksanaan pelayanan pendidikan melalui online di masa pandemic covid-19 yang tepat ditinjau dari segi Kekuatan, Kelemahan, Peluang dan Ancaman. Teknik Analisa data yang digunakan adalah Analisa SWOT (Strength, Weakness, Opportunities, Threats). Adapun yang dimaksud dengan analisis ini adalah untuk mengidentifikasi lingkungan internal dan eksternal sekolah dalam meningkatkan pelaksanakan pelayanan pendidikan melalui online di masa pandemic covid-19 Analisis SWOT yang digunakan yakni pendekatan secara kualitatif penelitian kualitatif yang dipadukan dengan analisis deskriptif. Pendekatan kualitatif merupakan suatu analisis yang digunakan tanpa mempergunakan perhitungan angka-angka, melainkan berdasarkan penilaian atau pendapat serta dasar-dasar yang dapat menunjang dalam pengambilan keputusan yang bersifat subyektif. Metode pengumpulan data yang dilakukan dalam penelitian ini diantaranya observasi, wawancara dan dokumentasi yang diperoleh dari kepala sekolah, guru, staff dan wali murid pada SDIT Bina Cendekia - Depok. Analisis pelaksanaan pelayanan pendidikan melalui online di masa pandemic covid-19 yang tepat bagi SDIT Bina Cendekia adalah meningkatkan standar pelayanan program pembelajaran melalui online di masa pandemic covid - 19, standar pelayanan manajemen melalui online di masa pandemic covid - 19, standar pelayanan sarana dan prasarana melalui online di masa pandemic covid - 19. Hal ini akan, berpengaruh dalam meningkatkan jumlah peserta didik pada tahun ajaran baru.
\end{abstract}

Kata Kunci: Analisis SWOT, Pelaksanaan Pelayanan Pendidikan melalui Online Di Masa Pandemic Covid19

\section{Analysis of the Implementation of Online Education Services During the Covid-19 Pandemic at SDIT Bina Cendikia, Depok}

\begin{abstract}
The research aims at finding the appropriate implementation of educational services throught online at pandemic covid-19 in terms of Strength, Weaknesses, Opportunities and Threats. In this research, the author applied the SWOT (Strength, Weakness, Opportunities, Threat) data analysis technique to identify the internal and external factors that could improve education services provided at the school. The author ran the SWOT analysis with qualitative approach combined with descriptive analysis. Qualitative approach means that the author ran the analysis without using figures calculation, but used survey and opinions as well as the basics that can support a subjective decision-making. Meanwhile, the data collection method in this research includes observation, interviews, and documentation gathered from SDIT Bina Cendekia principal, teachers, staffs, and students' parents. The analysis of the appropriate implementation of education services throught online in pandemic covid - 19 for SDIT Bina Cendekia concludes that the school should improve the standard of program learning services throught online at pandemic covid-19, management services throught online at pandemic covid-19, facilities services and infrastructure throught online at pandemic covid-19. The improvement is expected to lead to the increasing number of students' enrollment every year
\end{abstract}

Keywords: SWOT Analysis, The Implementation of Educational Services throught Online at Pandemic Covid $-19$ 


\section{PENDAHULUAN}

Pendidikan adalah landasan dasar untuk membentuk manusia yang cerdas, berkarakter, serta berakhlak mulia dalam berbangsa dan bernegara. Maka dari itu pendidikan harus berkualitas, pendidikan disebut berkualitas, apabila tenaga pengajar bermutu, manajemen yang baik dan didukung oleh sarana dan prasarana yang lengkap. Pelaksanaan pendidikan dapat dilakukan melalui jalur pendidikan formal, nonformal dan informal. Jalur pendidikan formal terdiri atas pendidikan anak usia dini (TK/RA), pendidikan dasar (SD/MI), pendidikan menengah (SMP/MTs dan SMA/MA), dan pendidikan tinggi (Universitas) (Suwartini, 2017).

Jalur pendidikan formal ini sebagai sarana untuk membentuk karakter generasi penerus bagi bangsa dan negara, pendidikan formal dimulai dari pendidikan anak usia dini (TK/RA) sampai pendidikan tinggi (Universitas) harus saling mendukung dan berkaitan satu sama lain. Dalam menghadapi tantangan persaingan di dunia pendidikan, diharapkan agar peserta didik mampu bersaing dalam kancah nasional maupun internasional. Hal ini agar dapat memotivasi peserta didik dalam mencapai apa yang dicita-citakan terutama untuk mencapai prestasi yang lebih baik dan terbaik (Hasanah, 2019).

Program pendidikan formal di Indonesia yang wajib dan sangat dasar untuk warga negara adalah pendidikan dasar sembilan tahun, yaitu enam tahun di Sekolah Dasar/Madrasah Ibtidaiyah (SD/MI) dan tiga tahun di Sekolah Menengah Pertama / Madrasah Tsanawiyah (SMP/MTs) (Undang-Undang Republik Indonesia, 2003). Selanjutnya adalah jalur pendidikan nonformal, jalur pendidikan ini di luar pendidikan formal yang diselenggarakan secara terstruktur dan berjenjang. Pendidikan nonformal diantaranya terdapat pada Pendidikan Anak Usia Dini (PAUD), serta pendidikan dasar adalah Taman Pendidikan Al-Qur'an (TPA). Kegiatan pendidikan ini yang banyak terdapat di masyarakat yang beragama Islam. Selain itu, ada juga berbagai kursus (kursus musik, menjahit, dan lain - lain) dan bimbingan belajar untuk anak usia TK sampai tingkat Sekolah Menengah Atas (SMA). Selanjutnya adalah pendidikan informal, jalur pendidikan ini terdapat pada lingkungan keluarga dan berasal dari lingkungan yang terbentuk dari kegiatan belajar. Biasanya kegiatan pendidikan informal ini dilakukan secara mandiri. Pendidikan ini bertujuan agar mencapai hasil yang lebih maksimal, yaitu dilakukan dengan secara sadar, tekun, mandiri dan bertanggung jawab (Hasanah, 2019)

Di Indonesia, SD (Sekolah Dasar) merupakan jenjang pendidikan formal yang paling dasar. Sekolah ini dapat ditempuh dalam waktu 6 tahun, di mulai dari kelas 1 sampai dengan kelas 6. Agar dapat mempengaruhi kelulusan peserta didik, saat ini peserta didik diwajibkan mengikuti UN (Ujian Nasional) yang diselenggarakan di sekolah. Kemudian, peserta didik dapat melanjutkan pendidikan kejenjang yang lebih tinggi yaitu Sekolah Menengah Pertama/sederajat yang dapat ditempuh selama 3 tahun (Sibi, 2016). Pada umumnya peserta didik SD (Sekolah Dasar) berusia 7-12 tahun. Di Indonesia, setiap warga negara berusia 7-15 tahun adalah wajib mengikuti pendidikan dasar, yakni Sekolah Dasar/sederajat selama 6 tahun, dan Sekolah Menengah Pertama/sederajat yang dapat ditempuh selama 3 tahun.

Sekolah dasar diselenggarakan oleh pemerintah maupun swasta. Sejak diberlakukannya otonomi daerah pada tahun 2001, pengelolaan sekolah dasar negeri (SDN) di Indonesia yang sebelumnya berada di bawah Departemen Pendidikan Nasional, kini menjadi tanggung jawab pemerintah daerah kabupaten/kota. Sedangkan Departemen Pendidikan Nasional hanya berperan sebagai regulator dalam bidang standar nasional pendidikan. Secara struktural, Sekolah Dasar Negeri (SDN) merupakan unit pelaksana teknis dinas pendidikan kabupaten/kota (Ibda \& Wijayanti, 2017, hal. 1). Sedangkan Sekolah Dasar Islam Terpadu atau SDIT adalah sekolah bagi Warga Negara Indonesia yang beragama Islam. Sekolah ini dapat digabungkan dalam dua metode pendidikan yaitu pendidikan reguler dan pendidikan aqidah/agama Islam. Dalam pendidikan reguler, mata pelajaran yang diajarkan sama seperti sekolah pada umumnya yaitu Matematika, IPA (Ilmu Pengetahuan Alam), Bahasa Indonesia, dan lain-lain. Sedangkan dalam pendidikan aqidah/agama Islam materi yang diajarkan berbeda dengan sekolah pada umumnya, seperti: tahfiz, hadist, BTQ/Baca Tulis Qur'an, dan sebagainya (Hawi, 2015). Aktivitas pengajaran di SDIT dengan cara menggabungkan kedua pendidikan, yaitu pendidikan reguler dengan pendidikan aqidah/agama Islam. Sehingga, waktu yang diperlukan lebih lama dibandingkan dengan lembaga sekolah lain, seperti: SDN, lembaga kursus, bimbingan belajar, dan lain-lain. Tidak bisa dipungkiri bahwa SDIT adalah rumah kedua dari rumah orangtua mereka yang merupakan rumah pertama mereka. Di sekolah inilah mereka dapat menuntut ilmu pengetahuan dan diharapkan sekolah ini dapat membentuk generasi yang Islami. Sehingga, sarana prasarana maupun fasilitas yang memadai sangat dibutuhkan dalam Kegiatan Belajar Mengajar, agar mereka nyaman, senang dan bahagia serta tidak merasa jenuh atau bosan dalam waktu yang lama di sekolah (Hasanah, 2019).

Covid-19 atau dikenal dengan Virus Corona adalah virus yang menggemparkan beberapa negara di dunia termasuk Indonesia. Pasalnya, virus ini sangat cepat sekali menyebar ke berbagai negara di dunia. 
Bahkan, saat ini WHO (World Health Organization) menyatakan bahwa wabah penyebaran virus sebagai pandemik di dunia. Covid-19 merupakan penyakit menular yang disebabkan oleh sejenis virus corona yang baru ditemukan dan wabah tersebut mulai tersebar pada bulan Desember tahun 2019 di Wuhan, Tiongkok (Munarsih, 2020). Dalam menanggulangi penyebaran Virus Covid-19 maka pemerintah Indonesia mempunyai beberapa kebijakan untuk memutus mata rantai penyebaran virus. Diantaranya: menghimbau agar masyarakat Indonesia melakukan penerapan social distancing atau physical distancing (menjaga jarak fisik), seperti: menghindari perkumpulan maupun kerumunan yang melibatkan banyak orang (Adrian, 2020). Kebijakan lain yang diterapkan oleh pemerintah adalah penerapan PSBB (Pembatasan Sosial Berskala Besar) peraturan yang diterbitkan Kementerian Kesehatan (Kemenkes) dalam rangka Percepatan Penanganan Covid19 yang harus dilaksanakan di berbagai daerah. Aturan PSBB berada dalam Peraturan Menteri Kesehatan Nomor 9 Tahun 2020 (JogloAbang, 2020). Selain itu, pemerintah menerapkan kebijakan Work From Home (WFH). Kebijakan ini diterapkan agar kegiatan pekerjaan maupun pembelajaran pada aspek pendidikan dilakukan di rumah. Banyak aspek yang kenyataannya berubah dengan adanya persebaran Virus Corona yang terjadi di berbagai negara. Diantaranya perubahan aspek di bidang teknologi, ekonomi, politik hingga pendidikan (Munarsih, 2020).

Pada aspek pendidikan Indonesia, sebelum masa pandemik sistem pembelajaran diterapkan melalui tatap muka yaitu KBM (Kegiatan Belajar Mengajar). Dengan adanya Covid-19, kegiatan pembelajaran tatap muka diganti dengan sistem pembelajaran online atau pembelajaran dalam jaringan (daring). Meskipun sistem pembelajaran online sudah diterapkan sebelum masa pandemik dan penerapannya tidak dilakukan secara terus menerus atau continue.Sehingga, banyak kendala yang dialami oleh para siswa selama pembelajaran online (Munarsih, 2020).

SDIT Bina Cendekia yang beralamat di Jl. Curug Raya, Rt 01/09, Kel. Curug, Kec. Bojongsari, Depok-Jawa Barat (16517). Didirikan pada tahun 2009/2010 oleh Yayasan Ar Romli Ibnu Tisan - Depok. Beroperasional tahun 2010/2011 dengan luas tanah $1105,8 \mathrm{~m}^{2}$ beserta luas bangunan $720,55 \mathrm{~m}^{2}$. SDIT ini hadir ditengah maraknya pertumbuhan Sekolah Dasar Islam Terpadu. Dengan penyajian sekolah yang bernuansa alam sebagai sekolah alternatif untuk anak-anak tingkat Sekolah Dasar. Sekolah ini bertujuan untuk membentuk generasi qur,ani yang unggul dan kompetitif, menghadirkan sistem pendidikan terpadu dengan metode 3T (Tahsin/ memperbaiki atau memperindah dalam membaca Al-Qur'an, Tahfidz/ menghafal Al-Qur'an, dan Talaqqi/ belajar membaca Al Qur'an secara langsung dibimbing oleh seorang guru).

SDIT Bina Cendekia mempunyai visi dan misi dalam membangun anak-anak bangsa. Visinya adalah membentuk generasi qur,ani yang unggul dan kompetitif. Sedangkan misinya adalah membangun keunggulan peserta didik berbasis multiple intelegensi, membangun pribadi yang kompetitif, membangun pendidikan berbasis Al Quran, dan membentuk akhlaq mulia sebagai generasi penerus bangsa. Hal ini didukung oleh staff pengajar dengan lulusan perguruan tinggi, sekolah dan pesantren yang berkualitas dan berpengalaman dalam bidang pendidikan, kurikulum standar Diknas, kurikulum Al-Qur,an, serta mempunyai muatan lokal dan ekskul untuk menunjang kegiatan belajar mengajar.

Sesuai dengan Permen Nomor 63 tahun 2009 bagian 4 tentang Cakupan Penjaminan Mutu Pendidikan pada Bab 4 yaitu tingginya kecerdasan kehidupan manusia dan bangsa yang mengacu pada mutu kehidupan manusia dan bangsa Indonesia yang komprehensif dan seimbang yang mencakup sekurangkurangnya: (1) mutu keimanan, ketakwaan, budi pekerti, dan kepribadian; (2) kompetensi intelektual, estetik, psikomotorik, kinestetik, vokasional, serta kompetensi kemanusiaan lainnya sesuai dengan bakat, potensi dan minat masing-masing; (3) muatan dan tingkat kecanggihan ilmu pengetahuan, teknologi, dan seni yang mewarnai dan memfasilitasi kehidupan; (4) kreatifitas dan inovasi dalam menjalani kehidupan (5) tingkat kemandirian serta daya saing; (6) kemampuan untuk menjamin keberlanjutan diri dan lingkungannya. Hal ini menunjukkan bahwa pendidikan sangat berperan penting dalam meningkatkan kualitas sumber daya manusia (Menteri Pendidikan Nasional, 2009).

Terwujudnya sumber daya manusia yang berkualitas, maka dalam pelaksanaan pendidikan sangat berperan penting untuk mewujudkannya. Salah satu diantaranya adalah wadah meningkatkan pelaksanaan pelayanan pendidikan melalui online di masa pandemic covid-19. Mempunyai standar pelayanan program pembelajaran melalui online di masa pandemic covid-19, standar pelayanan manajemen melalui online di masa pandemic covid-19, serta standar pelayanan sarana dan prasarana melalui online di masa pandemic covid-19. Hal ini akan mempengaruhi faktor penunjang untuk kemajuan dan kesejahteraan sekolah. Oleh karena itu, harus ada kerjasama yang baik antara kepala sekolah, wakil kepala sekolah, guru, murid, dan masyarakat. Di samping itu, pelayanan pendidikan yang masih kurang maksimal juga akan menghambat Kegiatan Belajar Mengajar melalui online. Sehingga, apa yang ingin dicapai oleh sekolah hasilnya kurang maksimal dan kurang memuaskan. Seperti: hasil pengajaran dalam ujian, interaksi peserta didik, dan sebagainya. 


\section{TINJAUAN PUSTAKA}

\subsection{Tinjauan Pustaka}

Manajemen dikatakan sebagai ilmu karena manajemen dapat dipelajari dan dikaji kebenarannya (Handoko, 2015, hal. 8). Manajemen juga dapat dikatakan sebagai suatu proses atau kerangka kerja, yang melibatkan bimbingan atau pengarahan suatu kelompok orang-orang kearah tujuan-tujuan organisasional atau maksud-maksud yang nyata (Terry \& Rue, 2016, hal. 1). Manajemen membutuhkan strategi, dimana strategi adalah serangkaian keputusan dan tindakan mendasar yang dibuat oleh manajemen puncak dan diimplementasikan oleh seluruh jajaran suatu organisasi dalam rangka pencapaian tujuan organisasi tersebut (Siagian, 2016).

Strategi pemasaran adalah alat fundamental yang direncanakan untuk mencapai perusahaan dengan mengembangkan keunggulan bersaing yang berkesinambungan melalui pasar yang dimasuki dan program pemasaran yang digunakan untuk melayani pasar sasaran tersebut (Tjiptono, 2014, hal. 6). 7P pemasaran dan alat pemasaran yaitu (1) Product, adalah segala sesuatu yang dapat ditawarkan kepada pasar untuk memuaskan suatu keinginan atau kebutuhan konsumen. Produk dapat berupa sub kategori yang menjelaskan dua jenis seperti barang dan jasa yang ditujukan kepada target pasar; (2) Price,adalah sejumlah uang yang mempunyai nilai tukar untuk memperoleh keuntungan dari memiliki atau menggunakan suatu produk atau jasa; (3) Place memiliki peranan yang sangat penting dalam membantu perusahaan guna memastikan produknya; (4) Promotion adalah semua kegiatan yang dilakukan perusahaan untuk mengkomunikasikan dan mempromosikan produknya kepada pasar sasaran; (5) People adalah proses seleksi, pelatihan, dan pemotivasian karyawan yang nantinya dapat digunakan sebagai pembedaan perusahaan dalam memenuhi kepuasan pelanggan; (6) Physical evidence adalah bukti yang dimiliki oleh penyedia jasa yang ditujukan kepada konsumen sebagai usulan nilai tambah konsumen. Bukti fisik merupakan wujud nyata yang ditawarkan kepada pelanggan ataupun calon pelanggan; dan (7) Process adalah semua prosedur aktual, mekanisme dan aliran aktivitas dengan mana jasa disampaikan yang merupakan sistem penyajian atas operasi jasa (Kotler, Philip T., Keller, Kevin Lane, 2014, hal. 4).

Perilaku konsumen sebagai suatu studi tentang unit pembelian-bisa perorangan, kelompok, atau organisasi. Masing-masing unit tersebut akan membentuk pasar sehingga muncul pasar individu atau pasar konsumen, unit pembelian kelompok, dan pasar bisnis yang dibentuk organisasi (Kotler, Philip T., Keller, Kevin Lane, 2014). Model perilaku konsumen memiliki tiga dimensi yaitu stimulus pemasaran dan stimulus lain, kotak hitam konsumen, dan respons konsumen. Stimulus yang dijalankan produsen atau pemasar, bisa berupa strategi bauran pemasaran (produk, harga, tempat, promosi), dan stimulus lain yang berupa kondisi ekonomi, politik, teknologi, dan budaya.

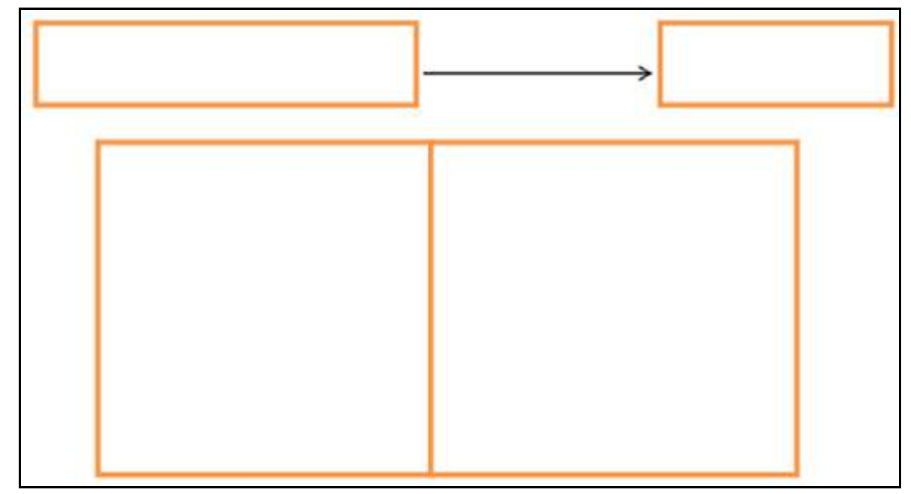

Gambar 1. Multiple stimuli consumer behavior

Kualitas pelayanan adalah suatu bentuk penilaian konsumen terhadap tingkat pelayanan yang diterima (received service) dalam tingkat layanan yang diharapkan (expected service) (Tjiptono, 2014 , hal. 151) sedangkan Pelayanan adalah manfaat atas aktivitas tidak berwujud yang ditawarkan oleh satu pihak kepada pihak lainnya dan tidak menghasilkan kepemilikan sesuatu (Kotler, Philip T., Keller, Kevin Lane, 2014, hal. 98). Secara garis besar, kualitas adalah sebuah kata bagi penyedia jasa dapat berguna dengan baik dan memiliki mutu yang bernilai harganya sementara pelayanan yang baik juga mendukung kualitas atau mutu dari perusahaan itu sendiri (Husain \& Sani, 2020). Jika layanan yang diberikan sesuai yang 
dikehendaki, maka konsumen akan mempunyai persepsi positif.

Kepuasan konsumen merujuk pada perasaan yang muncul dari seseorang senang atau kecewa ketika membandingkan antara persepsi atau kesannya terhadap suatu produk dan harapan-harapannya seseorang (Kotler, Philip T., Keller, Kevin Lane, 2014, hal. 150). Lebih lanjut, kepuasan adalah perasaan yang muncul senang atau kecewa setelah mengkomparasi hasil produk yang dipikirkan dan yang diharapkan (Kotler, Philip T., Keller, Kevin Lane, 2014, hal. 128). Kepuasan konsumen dapat diartikan sebagai suatu reaksi pelanggan yang telah merasakan suatu produk tertentu yang akan dijadikan bahan pertimbangan oleh masingmasing pelanggan untuk menentukan apakah pelanggan akan tetap menggunakan produk pilihannya atau memilih produk lain.

Standar Pelayanan Program Pembelajaran terdiri dari: (1) Standar Akreditasi merujuk Pasal 60 ayat (1) akreditasi dilakukan untuk menentukan kelayakan program dan satuan pendidikan pada jalur pendidikan formal dan nonformal pada setiap jenjang dan jenis pendidikan; ayat (2) akreditasi terhadap program dan satuan pendidikan dilakukan oleh Pemerintah dan/atau lembaga mandiri yang berwenang sebagai bentuk akuntabilitas publik; ayat (3) akreditasi dilakukan atas dasar kriteria yang bersifat terbuka (Undang-Undang Republik Indonesia, 2003); (2) Instrumen Akreditasi merujuk pada delapan komponen standar nasional pendidikan yang disusun oleh BSNP (Badan Standar Nasional Pendidikan) dan instrumen disusun dengan mengacu pada peraturan terkait yaitu standar isi, standar proses, standar kompetensi lulusan, standar pendidik dan tenaga kependidikan, standar sarana dan prasarana, standar pengelolaan, standar pembiayaan dan standar penilaian pendidikan.

\subsection{Kerangka Pemikiran}

Setiap sekolah mempunyai tujuan, secara umum tujuan sekolah adalah meningkatkan jumlah peserta didik dan mempertahankan sekolah dengan berbagai cara antara lain dengan meningkatkan pelaksanaan pelayanan pendidikan.

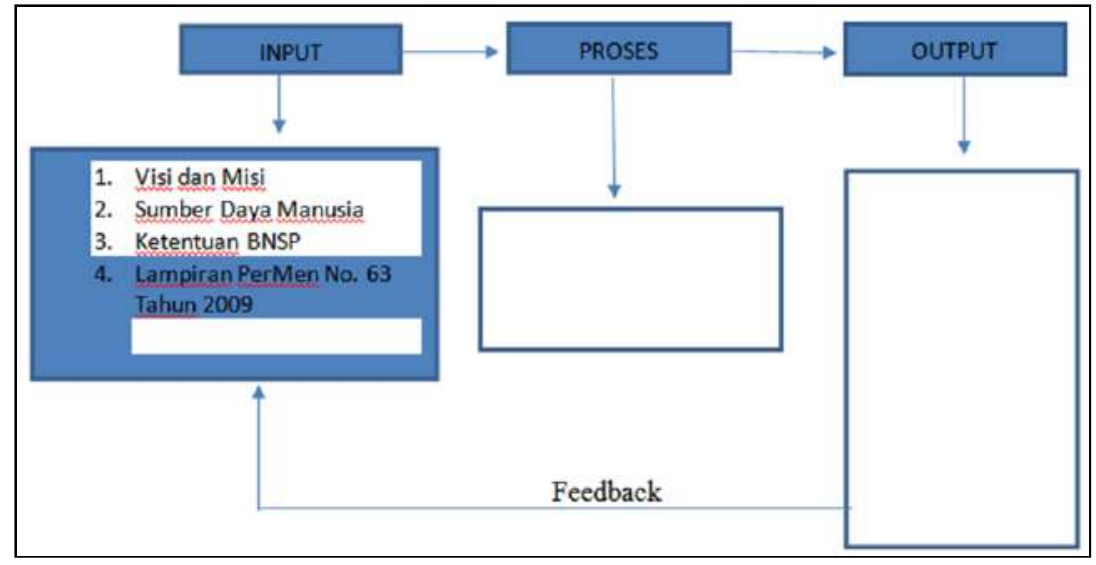

Gambar 2. Kerangka Pemikiran

Berdasarkan pada tinjauan pustaka dan kerangka pemikiran diatas, maka ditetapkan proposisi penelitian sebagai berikut:

1. Terdapat kelemahan dalam implementasi strategi pelayanan pendidikan pembelajaran online yang ditetapkan oleh SDIT Bina Cendekia di masa Pandemic Covid-19.

2. Akan terjadi peningkatan jumlah peserta didik yang masuk pada tahun ajaran baru pada masa yang akan datang.

\section{METODE PENELITIAN}

Penelitian ini merupakan riset deskriptif yakni tipe penelitian dengan rumusan masalah dengan suatu pertanyaan atas keberadaan variabel tunggal baik satu variabel maupun lebih dengan maksud tidak membandingkan variabel itu menggunakan sampel yang lain serta mencari hubunganya dengan variabel lainnya (Sugiyono, 2018). Penelitian ini menggunakan basis pendekatan yang bersifat kualitatif. Analisis kualitatif adalah proses mencari dan menyusun secara sistematis data yang diperoleh dari hasil wawancara, catatan lapangan, dan bahan-bahan lain, sehingga dapat mudah dipahami, dan temuannya dapat diinformasikan kepada orang lain (Sugiyono, 2018, hal. 244). Analisis data ini dilakukan dengan 
mengorganisasikan data, menjabarkannya ke dalam unit-unit, melakukan sintesa, menyusun ke dalam pola, memilih mana yang penting dan yang akan dipelajari, dan membuat kesimpulan yang dapat diceritakan kepada orang lain. Penelitian ini dilakukan pada SDIT Bina Cendikia yang beralamat di Jl. Curug Raya, Rt 01/09, Kel. Curug, Kec. Bojongsari, Depok, Jawa Barat - 16517. Penelitian ini dilakukan pada masa Pandemic Covid-19 pada SDIT Bina Cendekia Curug, Depok untuk meningkatkan pelaksanaan pelayanan pendidikan melalui online ini selama 6 bulan dari bulan Desember sampai dengan bulan Mei 2020 hingga tercukupi data dan informasi. Metode pengumpulan data menggunakan teknik wawancara mendalam dengan memilih key-informan. Metode analisis data merupakan proses pengumpulan data yang kemudian ditafsirkan dengan teknik dan upaya bekerja melalui data, mengorganisasikan data, mengkelompokkan menjadi kesatuan yang dapat diolah lebih lanjut, mengambil intisarinya, mencari dan menemukan pola menjadi penting untuk dipelajari serta menyimpulkan hal-hal apa saja yang dapat diinterpretasikan kepada pihak lain (Bogdan, 1982; Moleong, 2014)

\section{HASIL DAN PEMBAHASAN}

\subsection{Profil Subjek Penelitian}

Profil informasi dilakukan agar mendapat sumber data yang akurat dan dapat dipercaya. Dengan pertimbangan lama mengabdi di sekolah serta tugas dan wewenang yang dimiliki. Snowball sampling diharapkan sumber data dan informasi yang didapat sesuai dengan situasi dan kondisi/ keadaan sebenarnya di lapangan. Teknik sampling snowball sebagai salah satu teknik sampling yang dapat diandalkan untuk mendapatkan data dari responden guna menjawab permasalahan penelitian lapangan yang bersifat khusus. Dengan hal tersebut, maka ditetapkan 38 narasumber dalam penelitian ini, yaitu sebagai berikut:

a. Rosita, S.Pd.I Kepala SDIT Bina Cendekia

b. Munarsih, S.S., M.M. Wakasek/ Bidang Kurikulum SDIT Bina Cendekia

c. Firman Nurjamil, S.Pd.I Wakasek/ Bidang Keagamaan dan wali kelas

d. Erda Mayasari, S.Pd.I Wakasek/ Bidang Kesiswaan dan wali kelas

e. Firman Nurjamil, S.Pd.I Wali kelas 3

f. Orangtua murid kls 1 berjumlah 5 orang

g. Orangtua murid kls 2 berjumlah 5 orang

h. Orangtua murid kls 3 berjumlah 5 orang

i. Orangtua murid kls 4 berjumlah 5 orang

j. Orangtua murid kls 5 berjumlah 5 orang

k. Orangtua murid kls 6 berjumlah 5 orang

1. Guru mata pelajaran penjas

m. Guru mata pelajaran BTQ

n. Guru mata pelajaran bahasa inggris dan bahasa arab

o. Guru mata pelajaran Hadist

p. Guru mata pelajaran Tahfiz.

\subsection{Analisis Threat-Opportunity-Weakness-Strength (TOWS/ SWOT)}

Matriks TOWS atau SWOT merupakan matching tool yang penting (Umar, 2002, hal. 244). Hal ini untuk membantu para manajer mengembangkan 4 (empat) tipe strategi utama berdasarkan matriks TOWS/ SWOT sebagai berikut:

Tabel 1. Analisis TOWS/SWOT

\begin{tabular}{|c|c|c|}
\hline Faktor Internal & $\begin{array}{c}\text { Strength }(\mathbf{S}) \\
\text { Daftar } \\
\text { Kekuatan Internal }\end{array}$ & $\begin{array}{c}\text { Weaknesses }(\mathbf{W}) \\
\text { Daftar } \\
\text { Kelemahan Internal }\end{array}$ \\
\hline Opportunities (O) & Strategy (SO) Strategi yang & Strategy (WO) \\
\hline $\begin{array}{ll}\text { Daftar } & \text { Peluang } \\
\text { Eksternal } & \end{array}$ & $\begin{array}{l}\text { mengguna kan kekuatan } \\
\text { untuk me- manfaatkan } \\
\text { peluang }\end{array}$ & $\begin{array}{l}\text { Strategi yang memini- } \\
\text { malkan kelemahan untuk } \\
\text { memanfaatkan peluang }\end{array}$ \\
\hline Threats (T) & Strategy (ST) & Strategy $(\mathrm{WT})$ \\
\hline $\begin{array}{ll}\text { Daftar } & \text { Ancaman } \\
\text { Eksternal } & \end{array}$ & $\begin{array}{l}\text { Strategi yang mengguna } \\
\text { kan kekuatan untuk me- } \\
\text { ngatasi ancaman }\end{array}$ & $\begin{array}{l}\text { Strategi yang meminimal kan } \\
\text { kelemahan dan me- nghindari } \\
\text { ancaman }\end{array}$ \\
\hline
\end{tabular}


Semua variabel dalam penelitian ini dapat membantu dalam melakukan reformulasi strategi. Indiktator yang dipergunakan pada analisis SWOT disamakan dengan indikator yang dipergunakan pada analisis matriks space, sehingga terdapat kesinambungan dalam pemecahan permasalahan yang dihadapi oleh obyek yang diteliti, sehingga diperoleh solusi dengan tepat.

\subsection{Indikator Analisis SWOT}

Strength: (1) kesadaran akan pentingnya menjaga kesehatan di Masa Pandemic Covid-19. Menjaga kesehatan adalah hal yang sangat penting dalam mencegah berbagai penyakit, apalagi di masa pandemic covid-19. Pandemic ini membutuhkan imun kita kuat dan tidak terjangkit virus. Cara mencegahnya yaitu: dengan mencuci tangan, menggunakan masker, sarung tangan, serta menjaga jarak 1-2 meter/ tidak berkerumun dengan banyak orang; dan (2) Kesadaran akan penggunaan teknologi informasi Semakin meningkat. Adanya dampak di masa pandemik Covid-19 melalui pembelajaran online pada SDIT Bina Cendekia yang dapat dirasakan terutama oleh guru, siswa maupun orang tua siswa. Dengan penerapan pembelajaran online selama masa pandemik, maka kesadaran akan penggunaan teknologi informasi semakin meningkat agar pembelajaran semakin efektif dan efisien serta materi pembelajaran dapat tersampaikan dengan baik.

Weakness: (1) Guru kesulitan dalam menyampaikan materi melalui pembelajaran online. Beberapa kelemahan yang muncul akibat sistem pembelajaran online yang dihadapi pada masa pandemic Covid-19 diantara adalah guru memberikan tugas yang banyak karena materi pelajaran yang belum tersampaikan untuk siswa. Sehingga, siswa merasa terbebani dalam mengerjakan tugas. Belum lagi kendala sinyal yang lambat untuk mengakses informasi dalam jaringan (daring). Bahkan memory full pada handphone atau gadget karena banyak video maupun photo yang disave/disimpan oleh guru maupun siswa yang digunakan untuk mendukung proses pembelajaran online; dan (2) Guru kesulitan dalam menentukan metode pembelajaran yang tepat pada pembelajaran online. Metode pembelajaran tatap muka yang berubah menjadi metode pembelajaran online membuat guru merasa kesulitan dalam menentukan model pembelajaran apa yang tepat untuk diterapkan dalam menyampaikan materi pelajaran melalui sistem online.

Opportunity: (1) Guru dan siswa lebih kreatif dan dapat mengembangkan kualitas diri dengan penggunaan media tersebut guru dan siswa akan lebih kreatif dan dapat mengembangkan kualitas diri dengan menambah wawasan maupun ilmu pengetahuan. Yang paling utama adalah dapat mengatasi kejenuhan karena diterapkan kebijakan WFH (Work From Home) yang dilakukan secara terus menerus/continue selama masa pandemik Covid - 19; (2) Orangtua dapat memonitoring anak di rumah. Pada pembelajaran online, peluang yang dapat dirasakan oleh orangtua siswa, diantaranya: orangtua dapat membimbing anak secara langsung di rumah. Sehingga, orangtua dapat memonitoring/ mengawasi perkembangan anak dalam melaksanakan pembelajaran online dan hubungan antar orangtua dengan anak semakin erat. Hal ini akan mengakibatkan komunikasi yang baik antara orangtua dengan anak. Bahkan, akan mengurangi penggunaan gadget yang dirasa kurang bermanfaat untuk anak yang nantinya akan berdampak negatif pada perkembangan anak; dan (3) Guru dan siswa menguasai teknologi informasi digital online. Peluang lain yang dirasakan oleh guru, siswa maupun orangtua siswa diantaranya yaitu guru maupun siswa secara langsung dapat mempraktekkan dan menguasai teknologi informasi dengan menggunakan media pembelajaran melalui digital online. Kemudian, baik guru maupun siswa dapat menggunakan media pembelajaran jarak jauh sebagai fasilitas pembelajaran online, media pembelajaran yang digunakan melalui media sosial WhatsApp, youtube, e-learning, aplikasi zoom, google classroom dan sebagainya. Media digunakan agar materi pembelajaran tersampaikan dengan baik yang diberikan oleh guru kepada siswa.

Threat: (1) Kurangnya tingkat kepercayaan masyarakat terhadap kualitas guru dalam menyampaikan materi pembelajaran karena pembelajaran dilaksanakan melaui daring/online; (2)Tuntutan masyarakat yang tinggi dari orangtua murid terutama dalam hal bidang akademik maupun non akademik akan menghambat hubungan harmonis antara guru, siswa maupun hubungan dengan wali murid, hal ini karena pembelajaran jarak jauh dilaksanakan melalui online, sehingga sistem maupun metode pembelajaran akan berubah yang pada akhirnya akan mengakibatkan kurangnya tingkat kepercayaan orangtua terhadap kualitas sekolah maupun guru yang mengajar; (3) Pertimbangan orangtua dalam memilih SDIT akan menjadi ancaman bagi SDIT Bina Cendekia karena banyak SDIT lain yang bermunculan yang mempunyai keunggulan masing-masing serta lokasinya berdekatan dengan SDIT Bina Cendekia; (4) Minat peserta didik baru yang menurun untuk memilih SDIT, dengan adanya sistem pembelajaran online di masa Pandemic Covid-19 akan mempengaruhi tingkat jumlah peserta didik baru, karena kekhawatiran orangtua terhadap virus yang sedang mewabah saat ini tidak menutup kemungkinan minat peserta didik yang masuk pada tahun ajaran baru akan menurun; (5) Tingkat 
persaingan yang tinggi. Ancaman ini sangat berpengaruh pada jumlah peserta didik yang masuk di SDIT Bina Cendekia, karena dengan banyaknya SDIT yang bermunculan akan menjadi pertimbangan orangtua dalam memilih SDIT yang menurut mereka lebih baik.

\subsection{Evaluasi}

Berdasarkan hasil analisis SWOT pelaksanaan pelayanan pendidikan melalui pembelajaran online di masa Pandemic Covid-19 pada SDIT Bina Cendekia - Depok, bahwa pelaksanaan pelayanan pendidikan yang dilakukan adalah dengan menggunakan analisis Strength Opportunity (SO) menggunakan strategi kekuatan internal sekolah untuk memanfaatkan peluang eksternal. Strategi SO dicapai dengan menetapkan Strength Threats (ST), Weaknesses Opportunity (WO) dan Weaknesses Threats (WT). Strategi StrengthOpportunity (SO) yang dimiliki SDIT Bina Cendekia berdasarkan pada standar pelayanan program pembelajaran online, standar pelayanan manajemen melalui online, standar pelayanan sarana dan prasarana melalui online di masa pandemic covid-19 yang memberikan pedoman dalam mencapai tujuan sekolah.

\subsection{Pembahasan}

Untuk meningkatkan strategi pelaksanaan pelayanan pendidikan melalui online di masa pandemic covid-19 pada SDIT Bina Cendekia dalam strategi pelayanan program pembelajaran melalui online, strategi pelayanan manajemen melalui online, strategi pelayanan sarana dan prasarana melalui online. Dalam mewujudkan hal tersebut, ada beberapa pihak yang sangat berperan penting, diantaranya: kerjasama antar pihak sekolah dengan kepala sekolah, wakil kepala sekolah bidang kurikulum, wakil bidang keagamaan, wakil bidang peserta didik, guru dan staff. Kemudian, adanya kerjasama antara orngtua dengan guru dalam membimbing siswa di rumah dalam melaksankan system pembelajaran online. Hubungan yang haromis akan mengakibatkan meningkatnya kualitas pembelajaran yang lebih baik demi kelancaran pembelajaran melalui system online agar terlaksana secara efektif dan efisien. Kemudian, akan berpengaruh dengan meningkatnya peserta didik yang masuk pada tahun ajaran baru. Penelitian dilaksanakan pada SDIT Bina Cendekia untuk mengetahui pelaksanaan pelayanan pendidikan melalui online di masa pandemic covid-19 yang tepat ditinjau dari segi Kekuatan, Kelemahan, Peluang dan Ancaman. Teknik Analisa data yang digunakan adalah Analisa SWOT (Strength, Weakness, Opportunities, Threats). Adapun yang dimaksud dengan analisis ini adalah untuk mengidentifikasi lingkungan internal dan eksternal sekolah dalam meningkatkan pelaksanakan pelayanan pendidikan melalui online di masa pandemic covid-19. Berdasarkan hasil analisis SWOT strategi pelaksanaan pelayanan pendidikan pada SDIT Bina Cendekia - Depok, bahwa strategi pelaksanaan pelayanan pendidikan melalui online di masa Pandemic Covid-19 dilakukan melalui analisis SWOT, diantaranya: Strength, kesadaran akan pentingnya menjaga kesehatan di Masa Pandemic Covid-19 serta kesadaran akan penggunaan teknologi informasi semakin meningkat. Weakness, Guru kesulitan dalam menyampaikan materi melalui pembelajaran online dan dalam menentukan metode pembelajaran yang tepat. Opportunity, Guru dan siswa lebih kreatif dan dapat mengembangkan kualitas diri, orangtua dapat memonitoring anak di rumah serta guru dan siswa menguasai teknologi informasi digital online. Threat, kurangnya tingkat kepercayaan masyarakat terhadap kualitas guru dalam menyampaikan materi pembelajaran karena pembelajaran dilaksanakan melaui daring/online, tuntutan masyarakat yang tinggi, pertimbangan orangtua dalam memilih SDIT, minat peserta didik baru yang menurun untuk memilih SDIT dan tingkat persaingan yang tinggi.

Keunggulan SDIT Bina Cendekia dalam upaya meningkatkan strategi pelaksanaan pelayanan pendidikan melalui online di masa pandemic covid-19:

1. Strategi pelayanan program pembelajaran online

a. Pembelajaran dilakukan melalui system online dengan cara menggunakan metode pembelajaran yang sesuai serta menarik para peserta didik agar lebih giat belajar. Sehingga, penyampaian materi tersampaikan dengan efektif dan efisien.

b. Pembelajaran dilakukan dengan menggunakan media pembelajaran Pembelajaran Jarak Jauh (PJJ) sebagai fasilitas pembelajaran online, media pembelajaran yang digunakan melalui media sosial WhatsApp, youtube, e-learning, aplikasi zoom, google classroom dan sebagainya. Media digunakan agar materi pembelajaran tersampaikan dengan baik.

2. Strategi pelayanan manajemen melalui online

a. Bidang Peserta Didik

Peningkatan mutu sumberdaya manusia disesuaikan dengan visi dan misi sekolah agar terwujud dengan baik. Hal ini dapat dilaksanakan melalui pelatihan bagi para guru dan staff untuk memperluas wawasan maupun ilmu pengetahuan dalam menggunakan teknologi informasi di era digital.

3. Strategi Pelayanan Sarana dan Prasarana 
SDIT mempunyai sarana dan prasarana yang memadai diantaranya: lapangan sekolah yang digunakan untuk kegiatan pembelajaran, ekskul, maupun upacara bendera serta ruangan berAC untuk meningkatkan kenyamanan terutama bagi peserta didik. Namun, dengan adanya virus yang mewabah pada saat ini, sekolah meningkatkan sarana dan prasarana dengan menyediakan fasilitas internet untuk menunjang kebutuhan para guru dan staff dalam meningkatkan pelayanan melalui sistem online.

\section{PENUTUP}

Strategi pelaksanaan pelayanan pendidikan pada SDIT Bina Cendekia - Depok melalui analisis SWOT, diantaranya: Strength, kesadaran akan pentingnya menjaga kesehatan di Masa Pandemic Covid-19 serta penggunaan teknologi informasi semakin meningkat. Weakness, Guru kesulitan dalam menyampaikan materi dan menentukan metode pembelajaran yang tepat. Opportunity, Guru dan siswa lebih kreatif dan dapat mengembangkan kualitas diri, orangtua dapat memonitoring anak di rumah serta guru dan siswa menguasai teknologi informasi digital online. Threat, kurangnya tingkat kepercayaan masyarakat terhadap kualitas guru dalam menyampaikan materi pembelajaran, tuntutan masyarakat yang tinggi, pertimbangan orangtua dalam memilih SDIT, minat peserta didik baru yang menurun untuk memilih SDIT dan tingkat persaingan yang tinggi.

Beberapa saran penelitian ini yaitu:

1. Seleksi kepala sekolah sudah baik dan akan lebih baik jika kepala sekolah agar lebih mengembangkan diri dalam bertugas sebagai edukator (pendidik), manajer, administrator, supervisor, inovator, motivator, evaluator serta menjadi leader (pemimpin) yang dapat dipercaya, jujur, disiplin serta bertanggung jawab dalam memahami kondisi guru, staf dan peserta didik. Memiliki visi dan misi sekolah, berani mengambil keputusan, mempunyai gagasan baru untuk kemajuan sekolah dan sebagai tauladan dalam melaksanakan tugas.

2. Dengan adanya pelaksanaan pelayanan pendidikan melalui online di masa Pandemic Covid-19 pada SDIT Bina Cendekia sebaiknya dapat meningkatkan standar pelayanan program pembelajaran melalui online, standar pelayanan manajemen melalui online, standar pelayanan sarana dan prasarana melalui online karena akan berpengaruh dalam meningkatkan jumlah peserta didik pada tahun ajaran baru.

\section{DAFTAR PUSTAKA}

Adrian, d. K. (2020, Mei 27). Pentingnya Menerapkan Social Distancing Demi Mencegah COVID-19. Retrieved Juni 07, 2020, from https://www.alodokter.com/pentingnya-menerapkan-social-distancing-demimencegah-covid-19

Bogdan, R. C. (1982). Qualitative Research for Education: An Introduction to Theory and Methods. Boston London: Allyn and Bacon, Inc.

Handoko, T. (2015). Manajemen (Edisi 2). Yogyakarta: BPFE.

Hasanah, N. M. (2019). Penyelenggaraan Jalur Pendidikan Formal dan Nonformal (Studi Kasus di PAUD Terpadu Salsabila Al-Muthi'in Yogyakarta). Early Chilhood Islamic Education and Development , 1 (2), 8497.

Hawi, H. A. (2015). Sistem Full-Day School di Sekolah Dasar Islam Terpadu (SDIT) Studi Kasus di Izzuddin Palembang. Istinbath, 15 (2), 71-87.

Husain, T., \& Sani, A. (2020). Kepuasan Pelanggan Toko Online Yang Dipengaruhi Kualitas Produk Dan Layanan. e-Journal JITK , 5 (2), 291-296.

Ibda, H., \& Wijayanti, D. M. (2017). Siapkah Saya Menjadi Guru SD Revolusioner? Guru SD; Guruku, Gurumu, Guru Kita (Cetakan Ketiga). (A. Hasyim, Ed.) Depok: Kalam Nusantara.

JogloAbang. (2020, April 07). Permenkes 9 tahun 2020 tentang Pedoman PSBB dalam rangka Percepatan Penanganan COVID-19. Retrieved Juni 07, 2020, from https://www.jogloabang.com/kesehatan/permenkes9-2020-pedoman-psbb-rangka-percepatan-penanganan-covid-19

Kotler, Philip T., Keller, Kevin Lane. (2014). Marketing Management (15 ed.). New Jersey: Pearson Prentice Hall. 
Menteri Pendidikan Nasional. (2009). Peraturan Menteri Pendidikan Nasional Nomor 63 Tahun 2009 tentang Sistem Penjaminan Mutu Pendidikan. Jakarta: Kepala Biro Hukum dan Organisasi, Departemen Pendidikan Nasional.

Moleong, L. J. (2014). Metodologi Penelitian Kualitatif (Revisi ed.). Bandung: Remaja Rosdakarya. Mowen, J. C., \& Minor, M. (2002). Perilaku Konsumen. (D. K. Yahya, Trans.) Jakarta: Penerbit Erlangga.

Munarsih. (2020, Mei 29). Hikmah di Dunia Pendidikan Indonesia Pada Masa Pandemik Covid-19. Retrieved Juni 2020, from Akademika Tajuk: RakyatMerdekaNews: https://rakyatmerdekanews.com/2020/05/28/hikmah-di-dunia-pendidikan-indonesia-pada-masa-pandemikcovid-19/

Rangkuti, F. (2008). The Power Of Brands. Jakarta: Penerbit Gramedia.

Siagian, S. P. (2016). Manajemen Sumber Daya Manusia. Jakarta: Bumi Aksara.

Sibi, F. Y. (2016). Study of Availability of Education Facilities Servies in Jayapura City. 5 (4), 1-10.

Sugiyono. (2018). Metode Penelitian Evaluasi: Pendekatan Kuantitatif, Kualitatif, dan Kombinasi. Bandung: CV. Alfabeta.

Suwartini, S. (2017). Pendidikan Karakter dan Pembangunan Sumber Daya Manusia Berkelanjutan. Trihayu: Jurnal Pendidikan Ke-SD-an , 4 (1), 220-234.

Terry, G., \& Rue, L. W. (2016). Dasar-Dasar Manajemen. Jakarta: Bumi Aksara.

Tjiptono, F. (2014). Pemasaran Jasa- Prinsip, Penerapan, dan Penelitian. Yogyakarta: Andi Offset.

Umar, H. (2002). Strategic Management in Action. Jakarta: PT. Gramedia Pustaka Utama.

Undang-Undang Republik Indonesia. (2003). Undang-Undang Republik Indonesia Nomor 20 Tahun 2003 tentang Sistem Pendidikan nasional. $\quad$ Retrieved $2019, \quad$ from https://jdih.kemenkeu.go.id/fulltext/2003/20TAHUN2003UU.htm 